\title{
FORMATION OF "CLIP CULTURE" AND ITS IMPACT ON DEVELOPMENT AND SELF-IDENTIFICATION OF PERSONALITY IN INFORMATIONAL SOCIETY
}

\author{
CNIKITENKO, VİTALINA \\ Zaporizhzhia State Engineering Academy (Zaporizhzhia, Ukraine) \\ E-mail: vitalina2006@ukr.net, ORCID 0000-0001-9588-7836
}

\begin{abstract}
The urgency of the research is that the conditions for the formation of a "clip culture" of a virtual person in the virtual world are analyzed. The term "clip culture" was put into circulation by O.Toffler and compared with the virtual culture of the information society. Setting objectives. The problem of analysis is due to the fact that the person today is formed in an artificially created virtual world, which distorts the personality and forms its torn and inadequate image. This type of society as a virtual-online needs its interpretation and analysis of a new conceptual-categorical apparatus. Analysis of recent research and publications. A. Toffler, as one of the major theoreticians of the information society, has clearly defined the attributes of a new born culture - its figurative, de-massified, virtual character. Z. Baumann noted this situation, who wrote about the society of individuals, vulnerable fragmentation, "an individualized postmodern society". Problems of clip culture "of the virtual person of the postmodern era were also considered by D.Bayr, D.Bell, Dzh.Gelbright, M.Castells, J.Masud, V.Frexis and others. The selection of unexplored parts of the general problem is the conceptualization of the concept of "clip culture" and its discovery in the postmodern society. At the core of the study is the conceptualization of the basic schemes of "clip culture", which is synonymous with virtual, and revealing its influence on the development and selfidentification of the individual. The task statement is the use of synergistic methodology, which makes it possible to analyze the "clip culture" of the postmodern era and its impact on the personality. Presenting of the main material. To analyze the phenomenon of "clip art culture" as a social and cultural phenomenon; the influence of clip culture on personality in postmodern society is revealed; the attributes of clip art are defined - its figurative, demassified, virtual character. Conclusions - the concept of clip culture and its influence on the development and self-identification of the individual in the information society are formed.
\end{abstract}

Key words: clip culture, virtual person, information society, identity, self-identification, game, meaning

The problem is presented in general terms and its connection with important scientific or practical tasks.

Fragmentation, as well as the individualization of the virtual world, is due to the complication of the modern information society, the sharply increasing difficulties of adapting individuals, social groups, and institutions to a rapidly flowing reality that "crumbles" into a large set of subcultures. The very conditions of the information society require human adaptation to the changes generated by the rapid development of scientific and technological progress, which directly interferes in the inner world of man, influencing values, ethics, attitude towards politics, namely, the perception of the world "[1]. In this regard, not only the problem of human individuality, but also personal identity is actualized. One can compare: if in a traditional society the collective was over personal, then for information - the freedom of choice that an individual can realize in the format of his choice prevails.

A controversy took place, in connection with which for the first time a person becomes more relevant than identification, but attempts to realize themselves outside the boundaries of social ties and social affiliation. In the conditions of the information society, the formation of a

Formation of "clip culture" and its impact on development and self-identification of personality in informational society 
person occurs when the conditions for selfrealization are raised, but with the reduction of aspiration towards identity. The vital world of man in the space of virtual society has its own rules, which do not depend on national, traditional, communication cultures. Thus, the analysis of the "clip" (screen) culture, formed in the information age, becomes very relevant. Beginning in the 1970 's, philosophers have drawn attention to the fact that "cultural mutations" occur in society. This term was introduced by $\mathrm{H}$. Skolimovsky, who noted that the development of the potential of technology does not always lead to the flowering of culture. The technique should not only develop, but also lead to the development of spiritual principles of man, to expand spirituality [13, p. 76]. In today's information society there is a completely different situation - desocialization, which leads to the independence of man from the influence of culture on personality. This process is due to the fact that many people can not identify themselves with any culture that, for various reasons, a person is between a traditional and a modern (informational) culture that generates a so-called clip culture.

The analysis of recent researches and publications, which initiated the solution of this problem

A. Toffler, as one of the major theoreticians of the information society, has clearly defined the attributes of a new born culture - its figurative, de-massified, virtual character. Z. Baumann noted about this situation, who wrote about the society of individuals, vulnerable fragmentation, "an individualized information society". Problems of "clip culture" of the virtual person of the infectious society were also considered by J. Baire, D. Bell, J. Gelbright, M. Castells, J.Masud, V.Frexis and others.

Unsolved earlier part of the general problem. Setting objectives

Famous English scientist J. Bayrem in the work "Technozis: Death of the World" notes that new technologies lead to the appearance of "technological consciousness" of people, mental disorders, aggressiveness, a sense of alienation from society [, p. 76].
An American philosopher V. Verkiss believed that the technique of the twentieth century forms a "technological man." Its appearance is irreversible, so there is a contradiction between the technological revolution and the existential revolution. According to the scientist's forecast, the "technological man" will win, as the "technological culture", focused on science and technology, will reveal new possibilities of the human body "[p. 76].

The purpose of the research is to realize the conceptualization of the clip culture in the context of the development of informational discourse caused by the technological civilization that formed the "technological culture".

This goal is realized in a number of tasks:

- to analyze the phenomenon of "clip art culture" as a social and cultural phenomenon;

- to find out the influence of the clip culture on the personality in the information society;

- to determine the attributes of the new born culture - its figurative, disassigned, virtual character;

Object of research - the phenomenon of clip culture as a complex social and cultural phenomenon.

The subject of the research is the influence of the clip culture on the development and self-realization of the individual in the information society.

The methodology is the use of synergistic methodology, which makes it possible to analyze the "clip culture" as a complex social phenomenon of the information society and its impact on the person.

\section{Discussion of the problem}

O. Toffler proposed the term "blip culture" (screen, flickering), but this term evolved to the virtual meaning. The term "virtual culture", "virtual world", "virtual image" was more common. The very process of the origin of this culture was described by A. Toffler. "We live in a world of unconventional reflective bullying" [32, p. $181]$. 
The most important of all points of view - social, cultural, psychological is that thinking of images turns into thinking reflective (virtual) images. "Generation of the third wave" feels good among all this bombardment signals, they absorb a large amount of information in a short time, but also manage to monitor the trends that allow you to organize all these virtual images in a little mold. " [32, p. 182].

O. Toffler, as one of the major theoreticians of the information society, has clearly defined the attributes of a new born culture - its figurative, disassigned, virtual character. These features are inherent in human culture in general, because the object of human activity is the inert, virtual concept of "information", which nevertheless leads to real human actions. With the advent of postmodern era, the eclipse in the relationship between man and meaning disappears any unambiguous - now this is a purely gaming relationship. Equating the rights valid and conceivable, the game leads to an unlimited number of values, so the sense is by no means connected with the previous "reality". "And earlier people used the concept of" gaming space ", but only the game space of postmodern became infinite" [31, p. 25].

The following evolution has happened: if modernists fought with traditions and their supporters, then postmodern proclaimed the possibility of the existence and interaction of any traditions. Everything in postmodern, including traditions, can become the reason for the beginning of the game, turning into an energy of all new, unexpected meanings. A characteristic feature of postmodern is its output into space, which may include installations, technical devices and object dispositions, designed for the production of visual, sound and spatial effects. This type of artistic product is called "multimedia installation", which uses mixed technique.

Man has ceased to participate in real life and emotionally lives as if in a different dimension.

Free time, and not the production of material values and goods, as it was before, is increasingly beginning to affect the existence and consciousness of people.
There is an increasing awareness that material wealth and money, on the one hand, and the wealth of society, on the other, "are not the same thing", that the latter is free time. There is a situation of increasing mobility, in the context of which a person's culture is placed in the free choice of a set of attributes of a postmodern society. As a result, the person repeatedly passes from one subculture to another and each subculture contributes to the value world of the person [2, p. 14].

That is, having got freedom, society and the individual "lose" identity in the modernworld.

Z. Baumann noted this situation, who wrote about the society of individuals, vulnerable fragmentation, "an individualized postmodern society". "Impotence, insolvency - this is the name of postmodern disease, das Unbehagen der Postmodeme. And this is not an illness of non-use, but an inability to adapt. Not a horror caused by a violation of prohibitions, but a terror of freedom. Not demands that increase the capabilities of the individual, but helpless actions in vain search for a reliable and continuous way "[1, p. 126]. New information and communication technologies that did not become a means of socialization of the individual, but they became narcotic impact on the individual. The modern type of personality with a cliplike dimension of consciousness, with its moral, social, psychological qualities that destroy their own integrity and substitute its virtual characteristics and attributes of measurements of consciousness as chaotic, torn, non-systemic, was formed.

O. Toffler notes: "The third generation wave of culture casts a tendency to observe the tendencies that make it possible to organize all these virtual images in a somewhat whole" [p.182]. On the one hand, information is transformed from a means to a target, standardizing behavior, interests, preferences of people, from another increasing the negative effects of excessive human capture by the power of information, the difference between individual and group value orientations and, consequently, a sharp increase in subcultures. 
E. Toffler, a well-known theorist of the information society, considers "the personality of the future", which is deeply rooted in the dynamics of socio-cultural transformations. He repeatedly notes that the third wave is the product of dramatic changes in the rice imposed by society - not a new man, but a new social character. And this means that in accordance with the diversity, polyvariability, multi-centered information social system, the personality will also be a variety of role models and life styles. In the end, the emergence of "configurative" or "modular I" is a necessity in the conditions of the information society. "Modular person" - a person who is able to change the types of activities, can potentially fit into any sphere of the social system: organization, group, community, as well as easy to leave, change their own beliefs.

"The third wave changes the nature of identity ...

The transition to a heterogeneous, differentiated society implies that the individual is less connected with the context of his birth and has a great choice in selfdetermination. The arrival of the Third Wave is also due to the marked acceleration of the pace of social and cultural change, so that the identities that are elected become shorter, and people accept or refuse any components of their identities faster than ever "[20, p. 281-282].

Therefore, "The third wave is most rewarding for cognitive abilities and education, as well as for people who are capable of quick adaptation, to changes ... It will reward curious, curious people who aspire to find out what is happening and to influence what is happening, people, who are capable of owning themselves in conditions of chaos and incomprehensibility. It will be needed by people who ... may not have the skills in any other specialty, but have experience in some different fields and the ability to extrapolate ideas from one sphere to another. She will reward individuality and entrepreneurship "[20, p. 287].

A feature of the culture of real virtuality is that it forms a system in which the reality itself is completely immersed in virtual images. The development of computer networks leads to the formation of specific virtual communities, while there is a wide social and cultural differentiation. An important anthropological aspect is the problem of alienation. I. Negodaev especially emphasizes that "passive consumption of information forms the rigidity of thinking, deprives people of direct communication with each other, narrows personal space, leads to the loss of interpersonal communication."

The founder of virtualism N. Nosov singled out four specific attributes of virtual reality - relevance, interactivity, autonomy, and movement. Virtualization is understood as the movement of the main types of human activity from a social space into a virtual one. First of all, this relates to informational and communicative activity, which is massively transferred to online mode.

Media and interactive technologies create a communicative system in which reality is transferred to an artificial world, a world of virtual images that become not just means of information transmission, but also serve as a specific human experience.

If a man of the modern age perceived social reality as a natural dan, in which it was necessary to exist, the person of the postmodern era, aware of the artificiality of the virtual environment, increasingly perceives various artefacts of the virtual environment as possible alternatives to the social environment.

Since the time of I. Kant, the question of space is revealed in the context of the a priori of its occurrence in the human consciousness, since this space was considered a condition for the possibility of human existence. The existence of a virtual space indicates the polyness of being. Therefore, the basic idea of a virtual worldview is poliontism, which involves an analysis of the human psyche as a set of diverse realities that are not reduced to each other.

Virtualism refers to the ephemeral world, which is built in accordance with the logic of the objective world with small changes, resulting in a virtual existence acting as a parallel to the existing one. By 
combining the principles of the real world and the results of human creativity, a person begins to change what, according to his ontological status, is not subject to the human influence.

Computer virtual reality appears as a result of not only the development of information technology, but also acts as a social necessity, which enables a person to diversify the multi-interpretation of everyday life according to their desires.

An important feature of this process is interactivity, the participation of the consumer in the virtual continuum, which makes the person act as a form of mass creativity, as a kind of performance, which anyone can become a participant of. Computer virtual reality is seen as an alternative sphere of being, more attractive than objective reality, which generates new forms of escapism, psychological dependence of the individual from the virtual world and new forms of "absolutely virtual spirit."

In this sense, the works of G. Hegel become useful. The study of the works of $\mathrm{G}$. Hegel on the idea of the Absolute Spirit makes it possible to interpret the virtual reality in the sense that the absolute spirit is the root cause of the whole environment, which possesses self-awareness and the ability to create something.

The Absolute Spirit in the process of dialectical alienation manifests itself in the form of the surrounding world, nature and man. Then, after removing all contradictions, as a result of the development of thinking and human activity, the natural course of dialectical development returns it to itself, but in an updated form.

Specifically, this may mean the interpretation of the Hegelian category of the Absolute Spirit in the aspect of the philosophy of virtual reality.

Hegel's Absolute Spirit can be interpreted as a constant reality, which generates in the process of dialectical alienation the world of substantive reality as a virtual reality. The virtual reality as the dominant of the second nature is a sociocultural phenomenon that goes beyond the present and computer terminology. Virtual reality is a collection of all realities: corporeality, consciousness, will, internal qualities of man, each of which has a dual nature of existence - constant and virtual. Therefore modern philosophy represents a modern person as a real and virtual, real and idealized construct.

This suggests that replacing the naturalscientific or mechanistic ontology, conventionally called the Newtonian, comes the communicative-semantic or discursive ontology centered on by man as an autonomous simulacrum, various communities and social worlds. According to the new paradigm of world knowledge, the latter as a fundamentally polyonic one exists simultaneously within the framework of a single hypertext, which is constructed by the same principle according to which discourse is constructed.

Virtual reality has a holographic nature, which simultaneously combines the external structure of discourse (communicative modifications and their manifestations emoticons, pictures, slang) and its internal structure (the meanings that underlie communication).

The holography of this reality is manifested in the fact that it seems, at first glance, one-dimensional to one who does not recognize the hidden meanings in it, and, on the contrary, is multidimensional, since it is capable of generating creative information and the interaction of the external and internal environment in the minds of participants drawn in this reality. This property of virtual reality gives a person the opportunity to reproduce by means of informmodels the own image of objective reality, endowed with personal meanings.

\section{Conclusions}

Consequently, virtual reality is interpreted as an artificially reproducible sphere-continuum, in which an individual can be transformed into communicating with oneself and acting in many roles-the recipient and the reader, the co-author and the contemplative, constituting a novelevolutionary matrix of mental structuresmodels of consciousness and unconsciousness, forming their real and virtual world. Therefore, a person in the

Formation of "clip culture" and its impact on development and self-identification of personality in informational society 
dynamics of virtual communication space can modify its existence and its existence.

Within the synergistic approach, the person is treated as a self-regulating, selfgoverning system, that is, it has a certain set of mechanisms of self-regulation, in which the decisive role of the controlling factor is the individual system of values of the individual; as a folding information-ordered system capable in processes of interaction with the environment to adaptive selfcorrection and progressive evolution through the use of feedback mechanisms; as an open system that can exist in isolation from the surrounding natural and social environment.

Between the elements of this system, "personality-society" there is a peculiar dynamic balance, and any deviation from it serves as the main source of activity of the system "personality". The integrity of the individual is the result of a dynamic (unstable) equilibrium in the system of "personality-society", but this balance is constantly threatened by violations as a result of changes that take place in society.

The changes in the external environment themselves are a source of activity of the individual, which, adapting to fluid conditions, accumulates useful information, increases the level of its organization, develops. Thus, the changes taking place in society are the source of personal development and in this sense are useful to it. In the minds of a person there is a large "map of possibilities", potential ways of development, it receives a probabilistic, stochastic character, and the range of probabilistic ways of personality development is quite large: from high moments of self-expression to extreme degradation.

\section{СПИСОК ВИКОРИСТАНИХ ДЖЕРЕЛ}

1. Бауман 3. Индивидуализированное общество / 3. Бауман // Пер. с англ. под ред. В.Л. Иноземцева. М.: Логос, 2005. 390 с.

2. Воронкова В.Г. Концепции взаимосвязи человека, сознания, разума в контексте виртуально-информационного пространства // Философия и космология. 2013.

3. Voronkova V. The Formation of the Concept of Noosphere Development of Modern Society in the Conditions of Information Society. Philosophy \& Cosmology. 2016. Vol. 16. P.179-191

4. Інформаційне суспільство в світі та Україні: проблеми становлення та закономірності розвитку: колективна монографія.Запоріжжя: РВВ ЗДІА, 2017. 282 с.

5. Кастельс М. Информационная эпоха: экономика, общество, культура; пер. с англ. О. И. Шкаратана. М. : ГУ ВШЭ, 2000. 607 с.

6. Лазаревич А. А. Становление информационного общества: коммуникационноэпистемологические и культурно-цивилизационные основания; науч. ред. И. Я. Левяш. Минск : Беларуская навука, 2015. 537 с.

7.Lash S. Critiques of Information. - London, 2002

8. Масуда Й. Компьютопия. М.: Наука, 1988.

9. Максименюк, М. Ю., Нікітенко, В. О. Формування парадигми інформаційнокомунікативного суспільства як різновиду складної соціальної системи і взаємодії. Гуманітарний вісник Запорізької державної інженерної академії. Запоріжжя. 2016. Вип. 66. С. 266-278.

10. Мельник В.В. Полікультурність в контексті глобалізації: соціальнофілософський аналіз // Гуманітарний вісник Запорізької державної інженерної академії. 2005. Вип.22. С.217-229.

11. Нікітенко, В. О. Геокультурні цінності в умовах сучасного світового розвитку : соціально-філософський вимір // Гуманітарний вісник Запорізької державної інженерної академії. Запоріжжя. 2013. Вип. 54. С. 266-280. 
12. Nikitenko Vitalina . Geokulturnì values in today's world development: a sociophilosophical dimension// Humanitarian Bulletin of Zaporizhzhшa State Engineering Academy/M-of education and science of Ukraine, Zaporizhzhia State Engineering Academy. Zaporizhzhia.2013. Вип. 54.C. 266-280.

13. Нікітенко В.О. Геокультурні цінності в умовах сучасного світового розвитку: соціально-філософський вимір // Гуманітарний вісник Запорізької державної інженерної академії. 2013. Вип. 54. С. 266-280.

14. Переломова О.С. Інтертекстуальність як системотвірна текстово-дискурсивна категорія // Гуманітарний вісник Запорізької державної інженерної академії. 2008. Вип. 34. C.87-95.

15. Тоффлер Э. Третья волна. М.: Издательство АСТ. 1999.

16.Хлєбнікова А.А. Становлення і розвиток інформаційного суспільства в умовах глобалізації: теоретико-методологічний контекст // Гілея: науковий вісник. 2015. Вип. 92. C. $170-174$.

\section{REFERENCES}

1. Bauman, Z. (2002). Yndyvydualyzyrovannoe obshchestvo / Per. s anhl.; pod red. V.L. Ynozemtseva. M.: Lohos. 2002 [in Russian].

2. Voronkova, V. H. (2013). Kontseptsyy vzaymosvyazy cheloveka, soznanyya, razuma v kontekste vyrtual'no-ynformatsyonnoho prostranstva // Fylosofyya y kosmolohyya [in Russian].

3 Voronkova, V. (2016). The Formation of the Concept of Noosphere Development of Modern Society in the Conditions of Information Society. Philosophy \& Cosmology. Vol. 16. P.179 -191 [in English].

4. Informatsiyne suspil'stvo v sviti ta Ukrayini: problemy stanovlennya ta zakonomirnosti rozvytku: kolektyvna monohrafiya (2017). Zaporizhzhya: RVV ZDIA. 282 s.[in Ukrainian].

5. Kastel's, M. (2000). Ynformatsyonnaya épokha: ékonomyka, obshchestvo, kul'tura; per. s anhl. O. Y. Shkaratana. M. : HU VSHÉ. 2000. 607 s. [in Russian].

6. Lazarevych, A. A. (2015). Stanovlenye ynformatsyonnoho obshchestva: kommunykatsyonno-épystemolohycheskye y kul'turno-tsyvylyzatsyonnye osnovanyya; nauch. red. Y. YA. Levyash. Mynsk : Belaruskaya navuka. 537 s. [in Russian].

7. Lash, S. (2002). Critiques of Information. London [in English].

8. Masuda, Y. (1988). Komp'yutopyya. M.: Nauka [in Russian].

9. Maksymenyuk, M. YU. \& Nikitenko, V. O. (2016). Formuvannya paradyhmy informatsiyno-komunikatyvnoho suspil'stva yak riznovydu skladnoyi sotsial'noyi systemy i vzayemodiyi. Humanitarnyy visnyk Zaporiz'koyi derzhavnoyi inzhenernoyi akademiyi. Vyp. 66. P. 266-278 [in Ukrainian].

10. Mel'nyk, V. V. (2005). Polikul'turnist' v konteksti hlobalizatsiyi: sotsial'nofilosofs'kyy analiz // Humanitarnyy visnyk Zaporiz'koyi derzhavnoyi inzhenernoyi akademiyi. Vyp.22. P.217-229 [in Ukrainian].

11. Nikitenko, V. O. (2013). Heokul'turni tsinnosti v umovakh suchasnoho svitovoho rozvytku : sotsial'no-filosofs'kyy vymir // Humanitarnyy visnyk Zaporiz'koyi derzhavnoyi inzhenernoyi akademiyi. Vyp. 54. P. 266-280[in Ukrainian].

12. Nikitenko, Vitalina (2013). Geokulturnì values in today's world development: a sociophilosophical dimension// Humanitarian Bulletin of Zaporizhzhsha State Engineering Academyi. Vyp. 54. P. 266-280 [in English].

13. Nikitenko, V. O. (2013). Heokul'turni tsinnosti v umovakh suchasnoho svitovoho rozvytku: sotsial'no-filosofs'kyy vymir // Humanitarnyy visnyk Zaporiz'koyi derzhavnoyi inzhenernoyi akademiyi. Vyp. 54. P. 266-280 [in Ukrainian]. 
14. Perelomova, O. S. (2008). Intertekstual'nist' yak systemotvirna tekstovo-dyskursyvna katehoriya // Humanitarnyy visnyk Zaporiz'koyi derzhavnoyi inzhenernoyi akademiyi. Vyp. 34. P.87-95 [in Ukrainian].

15. Toffler, É. (1999). Tret'ya volna. M.: Yzdatel'stvo ACT [in Russian].

16. Khlyebnikova, A.A. (2015). Stanovlennya i rozvytok informatsiynoho suspil'stva v umovakh hlobalizatsiyi: teoretyko-metodolohichnyy kontekst // Hileya: naukovyy visnyk. Vyp. 92. P. 170-174 [in Ukrainian].

НІКІТЕНКО В. О. - кандидат філософських наук, доцент кафедри філософії та суспільних наук, Запорізька державна інженерна академія (Запоріжжя, Україна)

E-mail: vitalina2006@ukr.net, ORCID: 0000-0001-9588-7836

\section{ФОРМУВАННЯ «КЛІПОВӦ̈ КУЛЬТУРИ» ТА П̈Ї ВПЛИВ НА РОЗВИТОК І САМОІДЕНТИФІКАЦІЮ ОСОБИСТОСТІ В ІНФОРМАЦЙНОМУ СУСПІЛЬСТВІ}

Анотація.Актуальність досліджсення в тому, щуо проаналізовано умови формування «кліпової культури» віртуальної людини у віртуальному світі. Термін " кліпова культура» введений в обіг О.Тофрдером $i$ порівнюється 3 віртуальною культурою інформаційного суспільства. Постановка завдання.Проблема аналізу викликана тим, що особистість сьогодні формується у итучно створеному віртуальному світі, щсо спотворює особистість $i$ формує ї̈ розірваний $і$ нецілісний образ. Даний тип суспільства як віртуально-онлайнового потребує його тлумачення та аналізу нового понятійно-категорійного апарату. Аналіз останніх досліджень $\boldsymbol{i}$ публікацій. О. Тоффлер як один з найбільших теоретиків інформаційного суспільства достатньо чітко визначив атрибути нової народжуваної культури - ї̈ образний, демасифікований, віртуальний характер. Про ияю ситуацію відмічав 3. Бауман, який писав про суспільство індивідуумів, уразливих фрагментацією, «індивідуалізованого суспільства постмодерну». Проблемикліпової культури» віртуальної людини епохи постмодерну розглядали також Дж.Байрем, Д.Белл, Дж.Гелбрейт, М.Кастельс, Й.Масуда, В.Фрексіс та інші. Виділення недосліджених частин загальної проблеми конщептуалізація поняття «кліпова культура» та ї̈ виявлення в суспільстві постмодерну. В основі дослідження - концептуалізація базових схем «кліпової культури», яка є синонімом віртуальної, та виявлення ї̈ впливу на розвиток та самоідентифікаціюо особистості. Постановка завдання - використання синергетичної методології, що дає можливість проаналізувати "кліпову культуру» епохи постмодерну та ї̈ вплив на особистість. Виклад основного матеріалу. Проаналізувати феномен «кліпової культури» як сочіального та культурного феномена; виявлено вплив кліпової культури на особистість у постмодерному суспільстві; визначено атрибути кліпової культури - ї̈ образний, демасифікований, віртуальний характер. Висновки - сформовано концепцію кліпової культури та ї̈ вплив на розвиток і самоідентифікацію особистості в інформаційному суспільстві.

Ключові слова:кліпова культура, віртуальна людина, інформаційне суспільство, ідентичність, самоідентифікачія, гра, смисл

НИКИТЕНКО В. А. - кандидат философских наук, доцент кафедры философии и общественных наук, Запорожская государственная инженерная академия (Запорожье, Украина)

E-mail: vitalina2006@ukr.net, ORCID: 0000-0001-9588-7836 


\section{«КЛИПОВОЙ КУЛЬТУРЫ» И ЕЕ ВЛИЯНИЕ НА РАЗВИТИЕ И САМОИДЕНТИФИКАЦИЮ ЛИЧНОСТИ В ИНФОРМАЦИОННОМ ОБЩЕСТВЕ}

Аннотация. Актуальность исследования в том, что проанализированы условия формирования «клиповой культуры» виртуального человека в вирутальном мире. Термин «клиповая культура» введен в обиход О.Тоффлером и сравнивается с виртуальной культурой информащионного общества. Постановка задания. Проблема анализа вызвана тем, что личность сегодня формируется в искусственно созданном виртуальном мире, который вульгаризирует личность и формирует ее разорванныий $и$ нецелостный образ. Данный тип общества как виртуально-онлайновый требует его толкования и анализа нового понятийно-категориального аппарата. Анализ последних исследований и публикаций. О.Тоффлер как один из выдаюшихся теоретиков инфорационного общества достаточно четко определил атрибуты новой рождающейся культуры - ее образный, демассификованный, виртуальный характер. Об этой ситуаџии говорил 3. Бауман, который писал об обществе индивидуумов, пораженных фрагментацией «индивидуализированного общества постмодерна». Проблемы «клиповой культуры» виртуального человека эпохи постмодерна рассматривались также Дж. Байрем, Д. Беллом, Дж. Гелбрейтом, М. Кастельсом, Й. Масудой, Ф. Фрексисом и др. Выделение неисследованных частей общей проблемы концептуализаџия понятия «клиповая культура» $и$ ее выявление в обществе постмодерна. В основе исследования - концептуализация базовых схем «клиповой культуры», которая есть синонимом виртуальной, и выявление ее влияния на развитие и самоидентификацию личности. Постановка задания - использование синергетической методологии, которая дает возможность проанализировать «клиповую культуру» эпохи постмодерна и ее влияние на личность. Изложсение основного материала. Проанализирован феномен «клиповой культурьл» как сочииального и культурного феномена; выявлено влияние клиповой культуры на личность в постмодерном обществе; определены атрибуты клиповой культуры - ее образный, демассифицированный, виртуальный характер. Выводы - сформирована концепџия клиповой культуры и ее влияние на развитие и самоидентификацию личности в информационном обществе.

Ключевые слова: клиповая культура, виртуальный человек, информационное общество, идентичность, самоидентификация, игра, смысл.

Стаття рекомендована до публікації д.філософ.н., проф. О. П. Пунченко (Одеса, Україна) Надійшла до редколегіï: 10.06.2018 Прийнята до друку: 15.06.2018

Formation of "clip culture" and its impact on development and self-identification of personality in informational society 